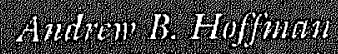

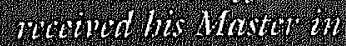

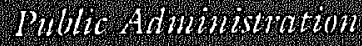

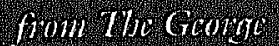

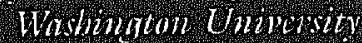

in Decomber 1008. It

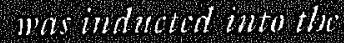

Pi Alphiz Alpha

national homons suciet)

tor public

adomimstintion in

Aloil 1008 ond nos the

relpint of the For

Motor Company

Hilowship in Junc

$100 \%$

1\%. Hoffmam is

currotly $a m p l o y e d$ by

the USS (rinem

- tcommtina Officons

ant thaluator in the

Administation of

Jusie lwme Aren,

whert he a nesponsible

for anditub fodoul

ilommal justice

programs and

ascltrintar thit

effitimenow and

filiuns

Pinn to onollmont

GWL, Horfman

performent ontrendl

dutiof for a lavo

natimal trats

abolation, acted as a

pors liaram for $a$

Wisshington, D)(-lonsid

think touk stetiolizing

ill dereghlotion polity.

and wolket as at

malsted finamial

reforentative for an

inlotment fom How

bis bowtotome of Was

Hollord, Commetiont.

Mr Hoffman

grontuatud firm

Kenvan Collene in

Gombict, Obio unith or

B.A. in Hism Ln hs

fint time be litie to in

line shate, molfolowal

ant apommit

\section{Reforming the Independent Counsel Act: A Call for Accountability}

Andrew B. Hoffman

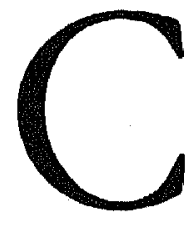

ontrary to current political sentiment, the Independent Counsel Act, while flawed, is not beyond repair. A product of the Watergate era, the Act was designed to eliminate the conflicts of interest that arise when the attorney general investigated allegations of wrongdoing in the executive branch. Although the Act has been effectively used in many instances, recent events illuminate how the statute can become politicized, serving as a vehicle for waging destructive political vendettas.

The original Independent Counsel Act required the Attorney general to ask a special three-judge panel to appoint a special prosecutor upon receipt of specific and credible evidence that a highranking government official committed an illegal act. ${ }^{1}$ This special prosecutor was authorized to conduct an investigation free of political interference and then submit findings of criminal wrongdoing to Congress for further action. 
Allowing the

statute to

expire would

be shortsighted,

as it ignores the

underlying

systemic and

societal

problems that

the Act

mitigates.
Unfortunately, the Independent Counsel Act took on a character that differed profoundly from these original intentions. After twenty independent counsel investigations, ${ }^{2}$ many of its flaws became obvious to politicians and legal experts as well as the general public. Among other weaknesses, the Act did not protect against partisan use of the office of the special prosecutor. Every aspect of the prosecutor's mission-from initial appointment to submission of a final report-can become infused with politics. Ironically, the statute designed to remove politics from sensitive, highlevel investigations, instead became a weapon to paralyze political opponents.

After June 30, 1999, the Independent Counsel Act will cease to exist unless Congress decides to reauthorize the statute. Allowing the statute to expire would be shortsighted, as it ignores the underlying systemic and societal problems that the Act mitigates. The numerous deficiencies of the statute do not override the original benefit that the Act servesinsuring that the objective, investigative duties of the attorney general are not compromised when high-level wrongdoings are investigated. The Independent Counsel Act should be retained, but modified by implementing the following reforms: limiting the scope of investigations and the targets of these inquiries; requiring that independent counsel candidates be apolitical; defining the level of offenses that require removal of the independent counsel from office; making decisions by an independent counsel to indict conform with established Department of Justice (DOJ) policies; and stipulating that independent counsel report their findings only in exceptional circumstances.
The redesigned Act that this paper proposes creates many benefits. The new legislation would serve specific constitutional purposes by providing for an impartial mechanism to investigate serious charges of high-level criminal acts. The proposed Act also responds to many of the features of the current Act that permit partisan exercise of the statute.

One of the original goals of the Independent Counsel Act was to enhance government's ability to police itself. While this important objective still exists, the new Act addresses the flaws that permitted politicized investigations. The model Act promotes the two critical attributes served by the original Act: maintaining public faith in government and ensuring that high-level cases of abuse of office 3 are expeditiously and impartially resolved.

\section{History of the Act}

The Independent Counsel Act was passed in 1978 as a component of the broader Ethics in Government Act (P.L. 95-521). The Act was designed to insulate investigations of executive branch officers from conflicts of interest by removing "prosecutorial discretion" 4 from the Attorney general in cases where high-ranking officials were accused of illegal acts.

The need for this institutional protection was recognized after the "Saturday Night Massacre" of 1973, when President Richard Nixon fired special prosecutor Archibald $\mathrm{Cox}^{5}$ for aggressively pursuing possible criminal acts by members of the Nixon administration in implementing and subsequently covering-up the Watergate burglary. These events 
showed that a president could unilaterally subvert the rule of law by dictating the terms under which high-ranking officials could be investigated.

Before Watergate, an attorney general could appoint a special prosecutor to look into specific incidences of high-level governmental corruption on an "ad hoc" basis. ${ }^{6}$ However, any pre-Watergate special prosecutor was under the control of the Attorney general and, therefore, subservient to the political preferences of executive branch leaders. Complicating the situation were the structural conflicts of interest inherent in the executive branch where the Attorney general is a political appointee beholden to the president, the chief of the executive branch. In developing the original independent counsel statute, Congress believed that a detached investigative office with separate authority would remove such conflicts of interest.

Watergate also illustrated the limitations of congressional power to oversee the president. A self-serving executive could influence investigative agencies to selectively pursue the wrongdoing of some people, while overlooking the misdeeds of others. The result was a breakdown in the universal application of the rule of law to political leaders. In response, the Independent Counsel Act created a prosecutor who had the institutional ability to resist political pressure. In addition, the Act gave the legislative branch direct oversight over independent counsels and required counsel to submit information to Congress that could potentially lead to impeachment. ${ }^{7}$ The Act ultimately made the executive more answerable to Congress and the American people.
The Supreme Court ruled on the constitutionality of the independent counsel statute after the law had been in effect for nearly a decade. In the 1988 landmark case Morrison v. Olson, ${ }^{8}$ three high-ranking officials in the Reagan Administration's Justice Department were accused of deliberately providing false testimony and withholding documents related to a congressional investigation of the administration's enforcement of the Superfund law.? Congress requested the attorney general to appoint an independent counsel to investigate the allegations against the three Justice Department officials.

The primary issue of the plaintiffs' case in the Supreme Court was a claim that the law violated the separation of powers doctrine established in the Constitution. The plaintiffs argued that establishing a prosecutorial entity not susceptible to executive branch authority reduced the president's ability to exercise his constitutional duty to enforce the law. The plaintiffs argued that since the investigation and prosecution of criminal acts was "quintessentially" an executive branch function, ${ }^{10}$ any abridgement of the president's ability to enforce the law was unconstitutional.

The Court rejected the plaintiffs' argument and upheld the law in a sevento-one ruling. ${ }^{11}$ The Court stated that an independent counsel, while separate from the executive branch, was still subject to the authority of the executive branch in ways that allowed the president to fulfill his or her constitutional duties. Specifically, the Court held that the following provisions conformed the Act to the separation of powers doctrine: the attorney general had the power to remove an independent counsel and delin-
The Act

ultimately

made the

executive more

answerable to

Congress and

the American

people. 
Also known as

a special

prosecutor, an

independent

counsel

possesses all

investigative

and

prosecutorial

powers granted

the

Department of

Justice (DOJ),

but is regarded

institutionally

and politically

as an

independent

agency. eate the subject matter over which the prosecutor had jurisdiction; no indepéndent counsel could be appointed without an express request from the attorney general; and the independent counsel could not "impermissibly" interfere with executive branch functions because of the temporary nature and limited jurisdiction of the special prosecutor. ${ }^{12}$

\section{Overview of the Act}

The Act mandates that the attorney general commence an investigation upon receipt of specific and credible evidence that an official covered by the Act "may have violated" a serious federal law. ${ }^{13}$ The Act applies to any "covered person," defined as any high-ranking executive branch official, including the president and vice-president. The rationale for including most high-level officials is that these officials have major policymaking roles and can exercise influence over governmental decisions that profoundly affect society. ${ }^{14}$ In addition, the chairman and treasurer of the national political committee seeking election or reelection of the president are also covered by the Act. ${ }^{15}$

The attorney general has thirty days upon receipt of accusatory information to determine its credibility and specificity and to decide whether a "preliminary investigation" is warranted. ${ }^{16}$ The attorney general has ninety days to complete the preliminary investigation if grounds for an investigation are justified. In the event that "reasonable grounds" do not exist to warrant further investigation, an independent counsel is not appointed. ${ }^{17}$ On the other hand, if ninety days pass and the attorney general has not filed a decision, an independent counsel is automatically appointed. If the attorney general concludes that reasonable grounds for a further investigation exist and "a personal, financial, or political conflict of interest" ${ }^{\prime 18}$ is present, the request for appointment of an independent counsel is forwarded to a special federal three-judge panel, known as the Division of the Court.

The Division of the Court, comprised of judges from the U.S. Circuit Court of Appeals for the District of Columbia, 19 appoints an independent counsel to investigate "the subject matter and all matters related to that subject matter." 20 Otherwise known as the Special Division, this judicial entity was created by the original Act. ${ }^{21}$ The Special Division selects an independent counsel with "appropriate experience" and defines the matters over which the independent counsel has jurisdiction. Criteria in choosing an independent counsel include related experience and an ability to conduct investigations in a "prompt, responsible, and cost-effective manner." 22

Also known as a special prosecutor, an independent counsel possesses all investigative and prosecutorial powers granted the Department of Justice (DOJ), but is regarded institutionally and politically as an independent agency. As such, an independent counsel can convene grand juries and prosecute wrongdoers. No time or resource limitations control independent counsel investigations. If a DOJ investigation coincides with the jurisdiction of an independent counsel, the authority of the independent counsel supercedes that of DOJ. Other provisions relating to the office include full reim- 
bursement of expenditures, complete access to relevant DOJ files, and permission to recruit DOJ personnel to help carry out investigative functions. Independent counsels cannot simultaneously hold any other position of "profit or trust under the United States." 23

The statute encourages the Special Division to allow the independent counsel a broad investigative jurisdiction. While the independent counsel must ask the attorney general to expand the established prosecutorial jurisdiction, the Special Division can approve an expansion if the independent counsel discovers evidence of illegal acts by persons who are outside the original jurisdiction. The Special Division also has authority to terminate an investigation by an independent counsel when all investigations within the counsel's jurisdiction are concluded.

To document the progress of investigations, independent counsel are required to submit reports detailing major expenses every six months and a final report describing the accomplishments of the independent counsel and the status of cases. This latter documentation is a catalyst for impeachment inquiries by the U.S. House of Representatives if "substantial and credible information" justifying impeachment is found. 24

Regarding oversight of independent counsel investigations, appropriate congressional committees are responsible for reviewing the conduct and progress of independent counsel. Congress also has the authority to request that the attorney general apply for appointment of an independent counsel. However, the attorney general is not obliged to honor such a congressional request. Furthermore, Congress can remove an independent counsel by impeachment and conviction, using the same process governing impeachment of a president.

The Act has been renewed three times since its original passage in 1978. The life of the statute was limited to five years in each reauthorization. Prior reauthorization resulted in only incremental changes to the Act, such as an expansion of the statute of limitations from two years to three years. ${ }^{25}$ This time around, the spectrum of possibilities as to what form, if any, the Act might take is considerably more broad.

\section{Benefits of the Act}

The positive aspects of the Independent Counsel Act have been largely overlooked in the current political debate over the law's reauthorization. This flurry of rhetoric condemning the Act ignores many of the fundamental benefits the Act provides to government, politics, and society.

The Independent Counsel Act allows for effective investigations of criminal acts in the executive branch while protecting against actual or perceived conflicts of interest. Proximity to the president puts the attorney general in a difficult situation when investigating his or her own administration. Even when an attorney general makes fact-based, neutral decisions during an investigation, the public could perceive those decisions as politically motivated because the attorney general serves at the pleasure of the president. 26 The perception that an investigation is based on the status or political persuasion of an individual, and
This flurry of

rhetoric

condemning

the Act ignores

many of the

fundamental

benefits the

Act provides to

government,

politics, and

society. 
Historically,

powerful

political

entities could

impede

investigations

of executive

\section{branch officials}

in order to

defend their

political

interests. not on the individual's illegal acts, reduces public faith that government executives are subject to the same prosecutorial standards as ordinary citizens.

Historically, powerful political entities could impede investigations of executive branch officials in order to defend their political interests. Accordingly, the central thesis of the Independent Counsel Act is that the attorney general is "disabled," and should be given a marginal role when conducting investigations where even a perceived conflict of interest arises. 27 Therefore, the statute limits the authority of the attorney general in matters that could lead to the appointment of a special prosecutor. For instance, the attorney general cannot grant immunity or issue subpoenas. ${ }^{28}$

The Independent Counsel Act serves important constitutional purposes. Under the Constitution, the executive branch has the power to prosecute criminal cases, while the legislative branch has the power to remove an executive branch official from office for committing an impeachable offense. Moreover, under the doctrine of separation of powers, which holds that each branch of government may exercise only those powers committed to it by the Constitution, the legislative branch can never pursue a criminal prosecution - even though a member of the executive branch may have committed a serious crime. The Independent Counsel Act respects the constitutional allocation of power while strengthening Congressional authority by giving Congress the option to ask for the appointment of an independent counsel when the Attorney general may be too weak or too intimidated to do so.

\section{Problems with the Current Legislation}

Despite the Act's benefits, serious problems damage the original legislation. For example, the offenses that the Act permits an independent counsel to pursue are often minor. Considering the gravity of both high-level corruption in the executive branch, as well as the impeachment that might result from an independent counsel investigation, independent counsels should only investigate serious abuses that occurred while the official was in office. Inviting independent counsel to investigate insignificant offenses trivializes both the Act and the serious wrongdoing the Act is supposed to address. The Independent Counsel Act should be the prosecutorial tool of last resort that is invoked only when profound or systemic damage to government has been done.

In addition, the statute applies insufficient safeguards to ensure that biased and malicious prosecutors cannot become prosecutorial tyrants. Under the current Act, the independent counsel has sole and uninhibited control over how an investigation is conducted. In addition, the breadth of an investigation can be widened to include any subject matter related to the original complaint. Therefore, the prosecutor has expansive discretion over whom to investigate and the extent to which the individual is investigated. A prosecutor with questionable motives can wreak havoc on the personal and political lives of the subjects of investigations.

Unlike regular prosecutors, whose limited resources lead them to make deliberate and thoughtful decisions to pros- 
ecute, independent counsel are provided with unlimited time and resources. Given these subsidies, independent counsel are not encouraged to resolve the immediate issue of guilt or innocence in an expeditious and cost-effective manner. In prosecutorial offices across the country, investigators determine the subjects of investigations based on facts that point toward culpability for criminal acts. However, available resources and "competing responsibilities" to prosecute other cases limit the extent of investigations. ${ }^{29}$ By contrast, because of the prior determination by the attorney general that an investigation was warranted, the independent counsel may be predisposed to finding evidence of guilt in order to show that the appointment was deserved. The special prosecutor, focusing on one individual, has the time, resources, and motivation to find some instance of wrongdoing, no matter how petty.

A negative externality of granting unlimited resources is that high-ranking officials are prosecuted more tirelessly for a broader range of crimes than are ordinary citizens. This type of reverse inequity means that an independent counsel is not likely to make him- or herself look incompetent by abandoning an investigation if the attorney general has determined one is warranted.

Although the current statute gives the attorney general the authority to fire a special prosecutor, the standard for removal, "good cause," 30 has been ambiguously defined. For instance, the Supreme Court recognized in Morrison that "misconduct" required removal from office. 31 This provision is subject to an extensive degree of interpretation, which can lead to potential abuses by independent counsel who argue that their questionable actions do not meet the stanclard of "good cause." The "good cause" limitation was enacted to separate independent counsel investigations from the will of the president. 32 However, the confusing standard has severely limited the attorney general's ability to terminate an unfit independent counsel.

Finally, the Act's reporting requirement increases the costs, duration, and intensity of investigations. The reporting requirement mandates that independent counsel write extremely detailed accountings of their activities. While the report is designed to display a counsel's findings, the requirement is a self-serving exercise which special prosecutors can use to justify their existence. Many independent counsels construct the final report concurrently with the investigation, which adds to the overall length of the inquiry. ${ }^{33}$ Furthermore, due to the highly charged nature of independent counsel investigations, reports can be used to embarrass political opponents, regardless of whether the targeted individual was indicted.

\section{The Model Act}

The model act that is proposed in this paper incorporates the beneficial aspects of the original Act, while also addressing its flaws. Five key provisions are essential for the redesign of the legislation. They are as follows:

- limiting the scope of independent counsel investigations, and to whom the statute applies;

\section{A negative \\ externality of \\ granting \\ unlimited \\ resources is \\ that high- \\ ranking \\ officials are \\ prosecuted \\ more tirelessly \\ for a broader \\ range of crimes}

than are

ordinary

citizens. 
Finally, the Act should be applied equitably, meaning prosecutions are conducted in the same manner for all

persons regardless of

position, political affiliation, or personal beliefs.
- enacting more stringent qualification standards for independent counsels;

- clarifying the policy for determining the level of criminal acts that warrant an indictment of a covered person;

- specifying those circumstances under which the attorney general can remove an independent counsel; and

- eliminating the reporting requirement unless impeachment is involved.

Some important factors helped guide this reformulation of the Independent Counsel Act. Cost minimization was a priority, as expenses incurred by the federal government in supporting an independent counsel investigation should be reasonable and cost-efficient. In addition, any reauthorization should strengthen public faith in government by enhancing the perception that investigations of executive branch officials are uncorrupted by political leadership. Finally, the Act should be applied equitably, meaning prosecutions are conducted in the same manner for all persons regardless of position, political affiliation, or personal beliefs.

\section{Provision One: Limiting the Scope of} Investigations, and to Whom The Act Applies

The first of the five provisions in the model act, limiting the scope of investigations, increases the accountability of the independent counsel to both the executive branch and the American people. This provision contains three main parts: limiting the range of people to whom the Act applies; limiting the duration of independent counsel investigations; and constraining the subject matter jurisdiction of independent counsel.

- The model act redefines "covered persons" to include all principal executive branch officers who are either elected or nominated by the president and confirmed with the advice and consent of the U.S. Senate. ${ }^{34}$ Covered persons include the president, vice-president, and all executive-level cabinet officials whose prosecution by the Department of Justice "may result in [the appearance of] a personal, financial, or political conflict of interest." 35 The provision in the current Act giving independent counsel the autbority to investigate nongovernmental people (U.S. Code, Title 28, Sec. 591(c)(1) is repealed;

This sub-provision makes the special counsel's jurisdiction the alleged wrongdoing of significant executive branch officials. Federal department heads are included because they are in charge of overseeing the administration and enforcement of federal laws. If a special prosecutor, in the course of his or her investigation, uncovers evidence of criminal acts by noncovered persons, the independent counsel can refer that evidence to the appropriate prosecutorial entity with jurisdiction.

However, in the current legislation, an independent counsel also has the power to investigate any person, from 
public officials to private citizens, whose investigation is a possible conflict of interest for DOJ. ${ }^{36}$ In this situation, a "regulatory" 37 or ad hoc independent counsel is appointed. Authority for appointing a regulatory independent counsel exists currently under DOJ regulations. 38

Limiting the range of people to whom the Act applies minimizes costs, as it would decrease the number of expensive and lengthy investigations undertaken by independent counsel.

- After an independent counsel is appointed, an investigation is autborized for two years to establish grounds to indict a covered person. Funding for independent counsel operations is limited to two years, with no opportunity to extend funding.

There is no time limit on prosecutions of matters arising out of the independent counsel's findings;

Although investigations of sophisticated, resourceful executive branch officials take time, two years is sufficient for an independent counsel to ascertain the factual circumstances that determine whether indictment and prosecution is deserved. Restricting independent counsel appropriations to two years minimizes governmental costs. Limited resources force a special prosecutor to assess whether prosecution of alleged crimes is feasible and encourages him or her to abandon any inquiries that are unlikely to produce satisfactory judicial results.

This provision promotes "prosecutorial discretion," a positive limitation on prosecutorial power that advances the equitable application of the statute.39 Prosecutorial discretion, an essential and beneficial check, is not an exact science, but it involves a calculation that considers the importance of cases, the resources available to prosecute a case, the public interest fostered by prosecution, and other forms of prosecutorial judgment. 40

This piece of the proposed legislation strengthens the statute's compliance with the separation of powers doctrine in the Constitution. The chief issue argued by the plaintiffs in Morrison, the case that established the constitutionality of the Independent Counsel Act, was that an independent counsel usurped a part of the president's law enforcement function. However, this provision establishes further avenues for control over the operations of independent counsel offices by the executive branch. It also ensures that an independent counsel cannot endlessly investigate high-level officials.

To conform the responsibilities of the Special Division to the two-year time limit on investigations, members of the Special Division serve for the duration of the investigation and cannot concurrently oversee any separate independent counsel investigations. This provision promotes efficiency in having the same Special Division members oversee the conduct and progress of the same independent counsel investigation. However, the two-year time limit ensures that judicial members of the Special Division do not become captured by an investigation.

- The independent counsel's jurisdiction is limited to matters
This provision

promotes

"prosecutorial

discretion," a

positive

limitation on

prosecutorial

power that

advances the

equitable

application of

the statute. 
With the

jurisdiction

restricted to

only direct

matters, a

prosecutor

cannot

investigate an

individual for

immaterial

reasons, such

as merely

having a prior

relationship

with a covered

person. directly related to the alleged

"criminal behavior. In other

words, only those matters that

bave direct evidentiary bearing

on the independent counsel's

issue jurisdiction are relevant.

The provision ${ }^{11}$ giving the

Division of the Court the power

to expand a special counsel's

jurisdiction, an action that bas

to be recommended by the

attorney general, is struck. The

statute is only invoked for

alleged criminal acts committed.

by covered persons while in

federal office;

Limiting the independent counsel's subject matter jurisdiction provides incentives for special prosecutors to conduct impartial investigations, as the process contains little leeway for extensive inquisitions of "questionable allegations." ${ }^{42}$ With the jurisdiction restricted to only direct matters, a prosecutor cannot investigate an individual for immaterial reasons, such as merely having a prior relationship with a covered person. Since investigations are focused on a single matter, spillover costs for other investigations are negated, which produces a faster resolution to the matter with less cost to the government.

This provision increases public faith in government by reducing the perception that the statute creates a runaway prosecutorial office, able to investigate anyone for any reason. Additional prosecutorial discretion is instituted by restraining the range of issues that the prosecutor can investigate, thus focusing the prosecutor on the criminal acts and not on the person. Restricting the range of subject matter also further's the equi- table application of the model act by making it impossible for independent counsels to pursue high-level officials for nonessential crimes.

\section{Provision 2: Enacting More Stringent Qualification Standards}

- The Division shall determine the suitability of independent counsel candidates using the following criteria: prosecutorial experience; financial interests completely separate from the target of the investigation or parties who stand to benefit from an investigation; full recusal from private practice; no prior relationsbips with entities advocating appointment; and credible, relevant third-party documentation as to the candidate's experience, abilities, and possible biases. If an official cbeck yields any conflict with the above standards, the candidate is ineligible to become an independent counsel;

By instituting tougher qualification standards, the model act ensures that candidates for the office of independent counsel will be judged according to important criteria that determine their suitability for the office.

Prosecutorial experience should be a primary qualification. Only experienced prosecutors who understand DOJ policies and procedures, have experience investigating high-profile cases, and are capable of exercising sound prosecutorial judgment should be recruited. An in- 
experienced independent counsel is more likely to regard an investigation as a research project designed to obtain every scrap of information instead of honing in on whether the information received and the type of offense would warrant a criminal indictment.

Although this provision proposes requirements for independent counsel candidates, minimal costs to the government are incurred in any investigation of the candidate's background. In addition, this option further minimizes costs by detecting conflicts of interest before an investigation commences. Removing a special prosecutor for conflicts of interest after the inquiry begins is costly and inefficient.

\section{Provision 3: Clarifying Official Policy} on Matters Warranting the Indictment of a Covered Person

- An independent counsel may only prosecute a covered person if the prosecution is consistent with established DOJ prosecutorial policy.

To prevent the statute from being used to prosecute the political opposition for trivial offenses, independent counsel are required to conform decisions regarding indictment to standard DOJ guidelines.

The objectives of this provision are twofold. First, adopting DOJ policy brings the independent counsel's prosecutorial discretion in line with established DOJ prosecutorial standards. Second, this provision keeps the special prosecutor focused on calculating the legal. viability of an indictment against a covered person.
This provision ensures that an independent counsel is unable to exercise arbitrary judgement in either continuing an investigation to produce political embarrassment, or prolonging an investigation based on trivial alleged offenses that DOJ would never prosecute. Quicker resolution of independent counsel cases also reduces expenditures.

Provision 4: Defining "Good Cause" that Justifies the Removal of an Independent Counsel

- An independent counsel can be removed by the attorney general for "good cause," which is defined as either violating established Department of Justice policies on prosecutorial conduct or generally accepted canons of legal etbics. The legislative requirement, in 28 U.S. Code, Section 596, that the attorney general submit a report detailing the findings of fact underlying an independent counsel's dismissal, is retained. An independent counsel can still seek judicial review of an attorney general's decision to remove by initiating a civil action in the United States District Court for the District of Columbia; ${ }^{43}$

The attorney general must have a clear threshold for ascertaining which legal or ethical violations by an independent counsel warrant dismissal. This provision provides that standard and increases the accountability of the independent counsel to the executive branch, which diminishes the possibility ...adopting

DOJ policy

brings the

independent

counsel's

prosecutorial

discretion in

line with

established

DOJ

prosecutorial

standards. 


\section{This provision}

provides that

standard and

increases the

accountability

of the

independent

counsel to the

executive

branch, which

diminishes the

possibility of a

free-wheeling

prosecutor

wielding

unchecked

power. of a free-wheeling prosecutor wielding unchecked power.

The requirement that the attorney general file a report substantiating the facts underlying the judgement to remove an independent counsel is maintained because of its prophylactic effect. The reporting requirement ensures that the attorney general bases his or her decision on facts that are substantial and credible.

Judicial review of an attorney general's decision to fire a special prosecutor is also retained to give an independent counsel an opportunity to appeal the decision if he or she thinks that the attorney general acted arbitrarily or was misinformed. Thus, the independent counsel can bring the issue to a federal district court that does not regularly oversee the actual investigation.

A significant benefit served by defining "good cause" is that future independent counsels are aware of the specific conduct that will result in termination. Prior knowledge of penalized activities of special prosecutors serves as a deterrent for engaging in conduct that is illegal or unethical.

Provision 5: Eliminating the Reporting Requirement

- The provision requiring an independent counsel to submit a final report to the Special Division detailing the independent counsel's work is repealed. 44 A report is only mandated if during the course of an investigation, an independent counsel receives substantial and credible information regarding offenses that may constitute grounds for impeachment. 45 The report is forwarded to the U.S. House of Representatives so that the legislative branch can perform its constitutional role in initiating the impeachment process.

By getting rid of the reporting requirement, except under special circumstances, the costs incurred by independent counsel investigations are reduced. The special prosecutor does not have to expend resources on constructing the report, which currently requires exhaustive documentation. ${ }^{46}$ Instead, the independent counsel can focus solely on deciding if the information received warrants an indictment against the covered person.

\section{Looking Ahead}

The current climate surrounding the Independent Counsel Act does not bode well for its reauthorization. Many senators, including those in each party's leadership, have spoken against any form of reauthorization. The Clinton administration's Justice Department, which pushed for the statute's renewal in 1993, ${ }^{47}$ testified on March 2, 1999 in favor of allowing the law to expire.

However, the political viability of the Independent Counsel is still strong. At recent congressional hearings, key senators expressed reservations about letting the law expire. Specifically, Republican senators were reluctant to give the attorney general sole discretion over appointing an independent counsel who would be under the direct authority of the Department 
of Justice. In addition, key senate Democrats with "memories of Watergate"4s were wary of completely vesting the authority to investigate highranking officials in the politically appointed attorney general.

Committees in both houses of Congress continue to examine the political and institutional feasibility of reauthorizing the independent counsel statute. Many former independent counsels, former attorneys general, and legal experts have advocated a variety of positions. At a hearing on March 25, 1999, before the Senate Governmental Affairs Committee, prior independent counsel, including Lawrence $\mathrm{E}$. Walsh who investigated the Iran-Contra issue during the Reagan administration, supported a reauthorization featuring strict limits on the scope of future investigations. ${ }^{49}$ One thing is certain: the debate will continue to rage.

\section{Conclusion}

The purpose of the Independent Counsel Act is to ensure that high-level officials are investigated in the same apolitical manner as regular citizens. However, current application of the independent counsel law has been anything but apolitical. High-level officials are prosecuted more tirelessly and are subjected to broader criminal inquiries than normal citizens. The fact that the law permits protracted investigations of the people subject to the Independent Counsel Act, instead of focusing on specific criminal offenses, warranted concern from Justice Scalia in 1988 and remains troubling today. 50
After a great deal of experience with the Act, it is time to shift the statute's legislative focus from establishing the independence of the special prosecutor to creating more accountability. This paper supports the continued existence of the independent counsel statute, but advocates major changes to the existing legislation. The model act seeks to reinforce the accountability of the independent counsel through provisions ensuring that inquiries conclude expeditiously, that independent counsel offices are shielded from politicized prosecutors, and that the special prosecutor can be effectively held accountable by the attorney general.

Significantly, the model act limits the scope of independent counsel investigations. These limits provide for quicker resolution of matters triggering the statute, with less cost, while still providing sufficient resources to facilitate an informed decision by an independent counsel on whether to indict a high-level official.

Additionally, tougher qualification standards minimize the chances that a prejudiced prosecutor can assume the responsibilities of an independent counsel. Mandating that prosecutorial decisions be based on Department of Justice policies ensures that the prosecutions do not result in farfetched indictments on frivolous grounds. The model act gives an attorney general final recourse to promote legal, institutional, and ethical accountability of the independent counsel. Lastly, the model act rescinds the reporting requirement in order to conform to common DOJ practices on the release of prosecutorial information and to protect the privacy rights of targeted individuals.

\section{If the current}

statute is

amended to

include the key

provisions

outlined in this

article, the Act

can become an

effective law

enforcement

tool. 
The

\section{fundamental}

purpose that

the Act was

intended to

serve,

instituting

"better

government

and better

\section{public trust in}

government," 51

remains an

important

function.
The Independent Counsel Act is an essential and worthy part of our governmental structure. If the current statute is amended to include the key provisions outlined in this article, the Act can become an effective law enforcement tool. The fundamental purpose that the Act was intended to serve, instituting "better government and better public trust in government," 51 remains an important function. This legislation cannot be abandoned simply because it has been used for self-interested purposes.

\section{NOTES}

1 Independent Council Act, 1996, U.S. Code, Title 28, Sec.591.

2 U.S. House of Representatives, Committee on the Judiciary, Independent Counsel. Accountability and Reform Act of 1997 (H.R. 117), 105th Congress, 1st session, 1997.

3 U.S. Senate, Committee on Governmental Affairs, Hearing on the Future of the Independent Council Act: Testimony of Lawrence E. Walsh, 106th Congress, 1st session, 24 March 1999.

${ }^{4}$ American Bar Association, Summary of Action Taken by the House of Delegates of the American Bar Assoctation. Section of Criminal Justice, Report to the House of Delegates, Recommendation. The Independent Counsel Act: Its Fistory, Problems and Solutions. (Chicago, IL: American Bar Association, 1993).

5 Dan Froomkin, "Frequently Asked Questions," Washington Post, 26 August 1998.

6 U.S. Senate, Committee on Governmental Affairs, Hearing on the Future of the Independent Council Act: Testimony of Curtis Emery von Kann, 106th Congress, 1st session, 24 February 1999.

7 Independent Council Act, 1996, U.S. Code, Title 28, Sec. 595.

8 Morison v. Olson, U.S. S. Ct. 487 U.S. 654 (1988).
9 Ibid.

${ }^{10}$ Morrison v. Olson, U.S. S. Ct. 487 U.S. 654 (1988), Dissent of Justice Scalia.

11 Alexia Morrison, telephone interview by the author, 11 March 1999.

12 Morrison v. Olson, U.S. S. Ct. 487 U.S. 654 (1988).

13 Independent Council Act, 1996, U.S. Code, Title 28, Sec. 591.

14 R. G. Vaughn, Conflict-of-Interest Regulation in the Federal Executive Branch. (Lexington, MA: Lexington Books, 1979).

15 Independent Council Act, 1996, U.S. Code, Title 28, Sec. 591.

16 Ibid.

17 Independent Conncil Act, 1996, U.S. Code, Title 28, Sec. 592.

18 Ibid.

19 U.S. House of Representatives, Committee on the Judiciary, Independent Counsel Accountability and Reform Act of 1997 (H.R. 117), 105th Congress, 1st session, 1997.

20 Ibid.

21 Morrison v. Olson, U.S. S. Ct. 487 U.S. 654 (1988).

22 Independent Council Act, 1996, U.S. Code, Title 28, Sec. 593.

23 Ibid.

24 Independent Council Act, 1996, U.S. Code, Title 28, Sec. 595.

25 William L. Armstrong, Independent Counsel Reautborization/Conference Report (H.R. 2939). (Washington, DC: U.S. Government Printing Office, 1987).

26 Ibid.

27 Morrison, interview.

28 Independent Council Act, 1996, U.S. Code, Title 28, Sec. 592.

29 U.S. Senate, Committee on Governmental Affairs, Hearing on the Future of the Independent Council Act: Statement of Robert S. Bennet, 106th Congress, 1st session, 3 March 1999. 
30 Independent Council Act, 1996, U.S. Code, Title 28, Sec. 596.

31 Morrison v. Olson, U.S. S. Ct. 487 U.S. 654 (1988).

32 Morrison v. Olson, U.S. S. Ct. 487 U.S. 654 (1988), Dissent of Justice Scalia.

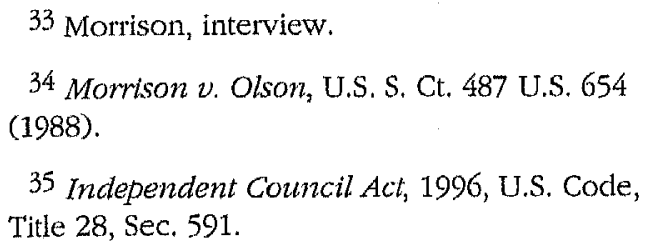
(1988).

35 Independent Council Act, 1996, U.S. Code, Title 28, Sec. 591.

36 U.S. Senate, Committee on Governmental Affairs, Hearing on the Future of the Independent Council Act: Testimony of Griffin $B$. Bell, King \& Spalding, 106th Congress, 1st session, 24 February 1999.

37 U.S. House of Representatives, Subcommittee on Commercial and Administrative Law, Committee on the Judiciary, Oversight Hearing on the Independent Council Law: Statement of Benjamin R. Civiletti, Venable, Baetjer, Howard E Civiletti, LLP, 106th Congress, 1st session, 10 March 1999.

38 Ibid.

39 U.S. House of Representatives, Subcommittee on Commercial and Administrative Law, Committee on the Judiciary, Oversight. Hearing on the Independent Council Law: Statement of Eric Holder, 106th Congress, 1st session, 2 March 1999.

40 U.S. Senate, Committee on Governmental Affairs, Hearing on the Future of the Independent Council Act: Testimony of Janet Reno, Attomey general, 106th Congress, 1st session, 17 March 1999.

41 Independent Council Act, 1996, U.S. Code, Title 28, Sec. 593(c).

42 Jerome J. Shestack, "Foreword: The Independent Counsel Act Revisited," Georgetown Law Journal 86 (July, 1998): 1-14.

43 Independent Council Act, 1996, U.S. Code, Title 28 , Sec. 596 .

44 Independent Council Act, 1996, U.S. Code, Title 28, Sec. 594(h)(1)(B).
45 Independent Council Act, 1996, U.S. Code, Title 28, Sec. 595(c).

46 Independent Council Act, 1996, U.S. Code, Title 28, Sec. 594(h)(1)(B).

47 Dan Morgan, "U.S. Reverses Position on Counsel Law," Wasbington Post, 2 March 1999.

48 Dan Morgan, "Senate Coalition Might Save Counsel Law," Wasbington Post, 18 March 1999.

49 Edward Walsh, "Investigation Veterans Back Counsel Law," Wasbington Post, 25 March 1999.

50 Morrison v. Olson, U.S. S. Ct. 487 U.S. 654 (1988), Dissent of Justice Scalia.

51 U.S. Senate, Committee on Governmental Affairs, Hearing on the Future of the Independent Council Act: Statement of Senator Joseph Lieberman, 106th Congress, 1st session, 24. February 1999.

\section{Bibliography}

American Bar Association. Anntual Report of the American Bar Association, Including Proceedings of the Fifi'-Second Annual Meeting of the House of Delegates beld at San Francisco, California, August 11-12, 1987. Volume 112, Number 2, Chicago, IL: American Bar Association, 1987.

American Bar Association. Summary of Action Taken by the House of Delegates of the American Bar Association. Section of Criminal Justice, Report to the House of Delegates, Recommendation. The Independent Counsel Act: Its History, Problems and Solutions. Chicago, IL: American Bar Association, 1993.

American Bar Association. Criminal Justice Section. Section of Litigation. Report to the House of Delegates Recommendation. Chicago, IL: American Bar Association, 8 February 1999.

Anderson, Philip S. "Summary of Action Taken by the House of Delegates of the American Bar Association." (Paper presented before the American Bar Association, New York, NY, August 10-11, 1993). 
Armstrong, William L. Independent Counsel Reautborization/Conference Report (H.R. 2939). Washington, DC: U.S. Government Printing Office, 1987.

Associated Press. "Judge Cites 24 Alleged Grand Jury Leaks." USA Today. 30 October 1998.

Associated Press. "Text of Reno's Petition for Starr." Washington Post. 29 January 1998.

Baker, Peter. "Under Fire, Starr Lays Out His Case." Wasbington Post, 19 November 1998.

Baker, Peter, and Eilperin, Juliet. "Inquiry May Turn Table On Starr, Jones Lawyers." Wasbington Post. 15 October 1998.

Baker, Peter, and Harris, John F. "Both Parties Seek End to Impeachment Drive." Wasbington Post. 9 November 1998.

Bendavid, Naftali. "Momentum Builds Against Independent Counsel Law." Cbicago Tribune. 24 February 1999.

Carney, Dan. "Reno, Freeh Appearance Sparks Posturing on Counsel Law." Congressional Quarterly (1997). Available from http://voter.cq.com/news/wn121601.htm; INTERNET.

Clark, David L. Financial Audit: Independent Counsel Expenditures for the Six Months Ended March 31, 1997. Washington, DC: U.S. General Accounting Office, 1997.

Clark, David L. Financial Audit: Independent Counsel Expenditures for the Six Months Ended Marcb 31, 1998. Washington, DC: U.S. General Accounting Office, 1998.

DiGenova, Joseph E. "The Independent Counsel Act: A Good Time To End A Bad Idea." Georgetown Law Journal 86 (July, 1998): 1520.

Editorial Staff. "Ms. Reno and Mr. Starr." Wasbington Post. 25 February 1999.

Froomkin, Dan, "Frequently Asked Questions." Wasbington Post. 26 August 1998.

Gullo, Karen. "Cost of Clinton Probes Exceeds \$40M." Associated Press. 30 September 1998.

Independent Council Act. 1996. U.S. Code, Title 28, Sec.591-596.

Kornblut, Anne E. "Prospect Dim for Counsel Statute." Boston Globe. 24 February 1999.
Lacey, Mark and Lichtblau, Eric. "Independent Counsel Law Faces Reform-Or Demise." Los Angeles Times. 24 February 1998.

Lardner, George Jr. "Bar Opposes Independent Counsels." Wasbington Post. 9 February 1999.

Marcus, Ruth. "Legal Guide: Untangling the Issues." Washington Post. 28 July 1998.

Morgan, Dan. "U.S. Reverses Position on Counsel Law." Washington Post. 2 March 1999.

Morgan, Dan. "Senate Coalition Might Save Counsel Law." Washington Post. 18 March 1999.

Morrison, Alexia. Telephone interview by the author, 11 March 1999.

Morrison v. Olson. U.S. S. Ct. 487 U.S. 654 (1988).

Morrison v. Olson, U.S. S. Ct. 487 U.S. 654 (1988). Dissent of Justice Scalia.

Office of the Independent Counsel. Referral to the United States House of Representatives Pursuant to Title 28, United States Code, 8 595(c). Washington, DC; U.S. Government Printing Office, 1998.

Ribicoff, A. Public Officials Integrity Act (P.L. 95521). Washington, DC: U.S. Government Printing Office, 1978.

Richard, Mark M. Response of Attorney general to Ann McBride's Call for an Independent Counsel. Washington, DC: U.S. Department of Justice, 1996.

Shestack, Jerome J. "Foreword: The Independent Counsel Act Revisited." Georgetown Law Journal 86 (1998): 1-14.

Sniffin, Michael J. "Holder Says Independent Counsel Law Needs Repair, Justice Panel Near Recommendations." Washington Post. 19 February 1999.

Snow, Tony. "Independent counsel statute cuts two ways." Detroit News. 20 October 1997.

Suro, Roberto. "Reno Rejects Probe of Gore on Lying." Wasbington Post. 25 November 1998.

Suro, Roberto, "Judges Get Involved in Probe of Starr." Wasbington Post. 24 February 1999.

Taylor, Stuart, Jr. "Time to Close Up Shop." Newsweek. 23 November 1998. 38. 
U.S. House of Representatives. Committee on the Judiciary. Independent Counsel Accountability and Reform Act of 1997 (H.R. 117). 105th Congress, 1st session, 1997.

U.S. House of Representatives. Committee on the Judiciary. Independent Counsel Limited Powers Act (H.R. 3464). 105th Congress, 2nd session, 1998.

U.S.House of Representatives. Committee on the Jucliciary, "Independent Counsel Act, Fact Sheet." (2 March 1999). Available from http://www.house.gov/judiciary/ 022699.htm; INTERNE'T.

U.S. House of Representatives, Subcommittee on Commercial and Administrative Law. Committee on the Judiciary. Oversight Hearing on the Independent Council Law: Statement of Benjamin R. Civiletti, Venable, Baetjer, Howard \& Civiletti, LLP. 106th Congress, 1st session, 10 March 1999.

U.S. House of Representatives. Subcommittee on Commercial and Administrative Law. Committee on the Judiciary. Oversight Hearing on the Independent Council Law: Statement of Eric Holder. 106th Congress, 1st session, 2 March 1999.

U.S. Senate. Committee on Governmental Affairs. Independent Counsel Reform Act of 1997 (S. 1065). 105th Congress, 1st session, 1997.

U.S. Senate. Committee on Governmental Affairs. Hearing on the Future of the Independent Council Act: Testimony of Curtis Emery von Kann. 106th Congress, 1st session, 24 February 1999.

U.S. Senate. Committee on Governmental Affairs. Hearing on the Future of the Independent Council Act: Opening Statement of Howard $H$. Baker Jr. 106th Congress, 1st session, 24 February 1999.
U.S. Senate. Committee on Governmental Affairs. Hearing on the Future of the Independent Council Act: Statement of Senator Josepb Lieberman on Independent Counsel Law Reautborization. 106th Congress, 1st session, 24 February 1999.

U.S. Senate. Committee on Governmental Affairs. Hearing on the Future of the Independent Council Act: Testimony of Griffin B. Bell, King \& Spalding. 106th Congress, 1st session, February 24, 1999.

U.S. Senate. Committee on Governmental Affairs. Hearing on the Future of the Independent Council Act: Statement of Robert S. Bennett. 106th Congress, 1st session, 3 March 1999.

U.S. Senate. Committee on Governmental Affairs. Hearing on the Future of the Independent Council Act: Testimony of Janet Reno, Attorney general. 106th Congress, 1st session, 17 March 1999.

U.S. Senate. Committee on Governmental Affairs. Hearing on the Future of the Independent Council Act: Testimony of Lawrence E. Walsh. 106th Congress, 1st session, 24 March 1999.

Vaughn, R. G. Conflict-of-Interest Regulation in the Federal Executive Branch. Lexington, MA: Lexington Books, 1979.

Walsh, Edward. "Key Sens. See End to Special Counsel Law." Washington Post. 1 March 1999.

Walsh, Edward. "Investigation Veterans Back Counsel Law." Wasbington Post. 25 March 1999. 
